\title{
Nonpsychotropic Cannabinoid Receptors Regulate Microglial Cell Migration
}

\author{
Lisa Walter, ${ }^{1}$ Allyn Franklin, ${ }^{1}$ Anke Witting, ${ }^{1}$ Christian Wade, ${ }^{1}$ Yiheng Xie, ${ }^{2}$ George Kunos, ${ }^{5}$ Ken Mackie,${ }^{3}$ and \\ Nephi Stella ${ }^{1,4}$ \\ Departments of ${ }^{1}$ Pharmacology, ${ }^{2}$ Neurology, ${ }^{3}$ Anesthesiology, and ${ }^{4}$ Psychiatry and Behavioral Sciences, University of Washington, Seattle, Washington \\ 98195, and ${ }^{5}$ National Institute on Drug Abuse and Alcoholism, National Institutes of Health, Bethesda, Maryland 20892
}

During neuroinflammation, activated microglial cells migrate toward dying neurons, where they exacerbate local cell damage. The signaling molecules that trigger microglial cell migration are poorly understood. In this paper, we show that pathological overstimulation of neurons by glutamate plus carbachol dramatically increases the production of the endocannabinoid 2-arachidonylglycerol (2-AG) but only slightly increases the production of anandamide and does not affect the production of two putative endocannabinoids, homo- $\gamma$ linolenylethanolamide and docosatetraenylethanolamide. We further show that pathological stimulation of microglial cells with ATP also increases the production of 2-AG without affecting the amount of other endocannabinoids. Using a Boyden chamber assay, we provide evidence that 2-AG triggers microglial cell migration. This effect of 2-AG occurs through $\mathrm{CB} 2$ and abnormal-cannabidiolsensitive receptors, with subsequent activation of the extracellular signal-regulated kinase $1 / 2$ signal transduction pathway. It is important to note that cannabinol and cannabidiol, two nonpsychotropic ingredients present in the marijuana plant, prevent the 2-AG-induced cell migration by antagonizing the CB2 and abnormal-cannabidiol-sensitive receptors, respectively. Finally, we show that microglial cells express $\mathrm{CB} 2$ receptors at the leading edge of lamellipodia, which is consistent with the involvement of microglial cells in cell migration. Our study identifies a cannabinoid signaling system regulating microglial cell migration. Because this signaling system is likely to be involved in recruiting microglial cells toward dying neurons, we propose that cannabinol and cannabidiol are promising nonpsychotropic therapeutics to prevent the recruitment of these cells at neuroinflammatory lesion sites.

Key words: microglia; migration; cannabinoids; glutamate; purinergic; kinase

\section{Introduction}

Marijuana intake produces a large variety of biological effects. These include the well known psychotropic effects, some adverse effects (e.g., memory loss, sedation, and motor impairment), and several beneficial effects (e.g., relief of muscle spasticity, analgesia, and reduction of inflammation) (Consroe et al., 1997; Hall and Solowij, 1998; Hampson and Deadwyler, 2000; Watson et al., 2000; Solowij et al., 2002). Because marijuana produces remarkable beneficial effects, patients with multiple sclerosis, for example, commonly use this plant as a therapeutic agent; however, we still lack essential information on the mechanistic basis of these beneficial effects (Lyman et al., 1989; Meinck et al., 1989; Wirguin et al., 1994; Martyn et al., 1995; Baker et al., 2000, 2001).

The marijuana plant, Cannabis sativa, contains $>60$ cannabinoid compounds, the best known being $\Delta^{9}$-tetrahydrocannabinol (THC), cannabinol (CBN), and cannabidiol (CBD) (for review, see Howlett et al., 2002). Cannabinoid compounds produce their biological effects by acting through at least three cannabinoid receptors (see Table 1). These include the cloned can-

Received Aug. 11, 2002; revised 0ct. 24, 2002; accepted Dec. 4, 2002.

This work was supported by National Institute on Drug Abuse Grants DA14486 (N.S.) and DA11322 and DA00286 (K.M.), a National Multiple Sclerosis Society grant (N.S.), and National Institute of General Medical Sciences and the Deutsche Forschungs Gemeinschaft fellowship awards (L.W., A.W.). We thank Sanofi Research for providing SR141716A and SR144528, Dr. Thomas Möller (University of Washington) for help with RT-PCR, and Dr. Elisabetta Blasi (University of Perugia, Italy) for BV-2 cells.

Correspondence should be addressed to Nephi Stella, Department of Pharmacology, University of Washington, 1959 Northeast Pacific Street, Seattle, WA 98195-7280. E-mail: nstella@u.washington.edu.

Copyright $\odot 2003$ Society for Neuroscience $\quad 0270-6474 / 03 / 231398-08 \$ 15.00 / 0$ nabinoid CB1 receptors, which are expressed predominately in the CNS (Matsuda et al., 1990), the cloned cannabinoid CB2 receptors, which are expressed predominately by immune cells (Munro et al., 1993), and the abnormal-cannabidiol-sensitive receptors (Járai et al., 1999) (hereafter referred to as abn-CBD receptors). The latter receptors have not been cloned yet, but they have been pinpointed pharmacologically in mice lacking $\mathrm{CB} 1$ and $\mathrm{CB} 2$ receptors and are also known as anandamide (AEA) receptors (Járai et al., 1999).

The induced psychotropic and adverse effects of marijuana are attributable to THC acting at $\mathrm{CB} 1$ receptors expressed by neurons (Mallet and Beninger, 1998; Zimmer et al., 1999; Hampson and Deadwyler, 2000; Huestis et al., 2001), whereas the immunomodulatory effects are attributable to THC and CBN acting at CB2 receptors expressed by immune cells and to CBD acting on abn-CBD receptors (Kaminski, 1998; Klein et al., 1998; Buckley et al., 2000; Malfait et al., 2000). Because CBN and CBD do not have significant intrinsic activity on CB1 receptors (Felder et al., 1995; Showalter et al., 1996), these compounds do not produce psychotropic and adverse side effects (Perez-Reyes et al., 1973), which makes them promising candidates as anti-inflammatory therapeutics. It should be emphasized that plant cannabinoids often act as partial agonists on cannabinoid receptors (Howlett et al., 2002), which suggests that they might antagonize the efficacious effects of certain endocannabinoids (i.e., the endogenous cannabinoid ligands produced by cells) (Piomelli et al., 1998; Stella and Piomelli, 2001).

Whether plant cannabinoids or endocannabinoids affect mi- 
croglial cells, the immune cells of the CNS, is poorly understood. Microglial cells are macrophage-like cells that originate from myeloid tissue and migrate into the developing CNS (Rezaie and Male, 1999). Once this early wave of microglial cell migration is completed, these cells remain in the CNS and become quiescent, a resting state that lasts as long as the CNS remains healthy. Quiescent microglial cells have a ramified morphology and express plasma membrane receptors, enabling them to survey the CNS and respond to pathological events (Kreutzberg, 1996). For example, microglial cells express purinergic receptors that detect ATP, which is released in high amounts by dying cells (Möller et al., 2000; Kim et al., 2001). Engagement of plasma membrane receptors on quiescent microglial cells initiates a rapid, multiplestep change in phenotype that is referred to as microglial cell activation (Kreutzberg, 1996; Bruce-Keller, 1999; Becher et al., 2000). Initially, quiescent microglial cells retract their ramifications, transforming themselves into amoeboid-like cells with motile protrusions (Stence et al., 2001). They then migrate toward the site of injury, where they release proinflammatory cytokines and cytotoxic agents (Kreutzberg, 1996; Bruce-Keller, 1999; Becher et al., 2000). Thus, as the initial step, microglial cell migration plays a crucial role in the propagation of the neuroinflammatory response; however, the signaling molecules that trigger microglial cell migration are poorly understood. We sought to determine whether plant cannabinoids and/or endocannabinoids regulate microglial cell migration and assessed whether pathological conditions affect endocannabinoid production from neurons and microglial cells.

\section{Materials and Methods}

Cells in culture. Newborn mouse neopallia microglial cells in primary cultures were prepared as described previously (Walter et al., 2002). BV-2 cells, a mouse microglial cell line, were grown in DMEM supplemented with FBS (3\%), penicillin (100 U), and streptomycin $(100 \mu \mathrm{g} / \mathrm{ml})$ and passaged every $3-4 \mathrm{~d}$ for a maximum of 30 passages. Because microglial cells and BV-2 cells were routinely grown with FBS, cells were recovered in a defined cell culture medium $\sim 18 \mathrm{hr}$ before experiments. Specifically, we recovered them at 200,000 cells/ml MEM/Cellgro (Mediatech, Herndon, VA) (MEM supplemented with 10 mм HEPES, 5 mм $\mathrm{NaHCO}_{3}, 100$ U penicillin, $100 \mu \mathrm{g} / \mathrm{ml}$ streptomycin, $2 \mathrm{~mm}$ L-glutamine, and $10 \%$ Cellgro) (Walter et al., 2002). Newborn mouse neopallia neurons in primary cultures were prepared in B27-supplemented Neurobasal as described by Stella and Piomelli (2001).

Reverse transcription-PCR. To perform reverse transcription (RT), we used superscript first-strand synthesis (Invitrogen, Grand Island, NY). The following mouse cannabinoid receptor primers were used: $\mathrm{CB} 1$ forward, 5'-TCT GGC CTA TAA GAG GAT CGT CAC-3'; CB1 reverse, 5' -CAG CAG GCA GAG CAT ACT ACA GAA-3'; CB2 forward, $5^{\prime}$-GGG TCC TCT CAG CAT TGA TTT CT-3'; and CB2 reverse, 5'-GTT AAC AAG GCA CAG CAT GGA AC- $3^{\prime}$. Amplification was performed by 35 cycles of the following: $94^{\circ} \mathrm{C}$ for $30 \mathrm{sec}, 63^{\circ} \mathrm{C}$ for $\mathrm{CB} 1$ primers and $57^{\circ} \mathrm{C}$ for $\mathrm{CB} 2$ primers for $30 \mathrm{sec}$, and $72^{\circ} \mathrm{C}$ for $2 \mathrm{~min}$. Amplification cycles were followed by $72^{\circ} \mathrm{C}$ for $10 \mathrm{~min}$. RT-PCR products were separated on $1.2 \%$ agarose gels, sequenced, and validated by comparison with the National Center for Biotechnology Information database. Absence of RT-PCR product in the "no RT" reaction confirmed the absence of genomic DNA in the samples.

Immunocytochemistry. To visualize actin filaments cells were fixed with paraformaldehyde and stained as follows: polyclonal rabbit anti-Cterminal CB1 (1:500) (Hájos et al., 2000), polyclonal rabbit anti-Cterminal CB2 (1:500; the antigen was constructed in our laboratory and the antibody was generated by R \& R Research and Development, Stanwood, CA), polyclonal rat anti-MAC1 (1:100; Serotec, Oxford, UK), monoclonal mouse-anti-hemagglutinin 11 (HA11) (1:500; Covance Research Products, Princeton, NJ), or with Texas Red-conjugated phalloidin (1:40; Molecular Probes, Eugene, OR). Secondary IgG antibodies were conjugated with Texas Red (1:100) or FITC (1:150; Jackson ImmunoResearch, West Grove, PA). Human embryonic kidney (HEK)293 cells were transfected with $1 \mu \mathrm{g}$ of construct for hemagglutinin epitopetagged rCB2 (HA-rCB2/pcDNA3) using $10 \mu \mathrm{l}$ of Superfect (Qiagen, Hilden, Germany). Images were acquired with a Leica (Nussloch, Germany) TCS SP/NT confocal microscope (Keck Center, University of Washington, Seattle, WA). Nonspecific staining was determined customarily with parallel immunostaining experiments performed in the presence of the appropriate immunizing antigen and using equal gain settings during acquisition and analysis.

Cell migration. Cannabinoid compounds were dissolved at $1000 \times$ in DMSO in silane-treated glass vials and added to the lower wells of the Boyden chambers with silane-treated pipette tips. BV-2 cells $\left(5 \times 10^{4}\right.$ in $50 \mu \mathrm{l}$ of MEM plus $10 \%$ Cellgro) were added to the upper chamber and allowed to migrate through polycarbonate filters (pore size, $10 \mu \mathrm{m}$ ) for 3 hr at $37^{\circ} \mathrm{C}$ (humidified atmosphere of $95 \%$ air and $5 \% \mathrm{CO}_{2}$ ). Cells that did not migrate and stayed on the upper surface of the filter were wiped off, whereas cells that had migrated to the lower surface were stained with the DIF-Quick stain kit (IMEB, Inc., San Marcos, CA) and manually counted in random fields at $32 \times$ magnification by three scorers that were blind to experimental conditions.

Chemical ionization gas chromatography/mass spectrometry analysis of endocannabinoids. Endocannabinoids were analyzed in two compartments: (1) cells plus adjacent media and (2) distant media. We decided to keep cells covered with their adjacent media to prevent air-induced stress.

Microglial cells, BV-2 cells, and neurons plated in $100 \mathrm{~mm}$ culture dishes were placed on a shaking water bath kept at $37^{\circ} \mathrm{C}$, keeping them in their defined cell culture media $(12.5 \mathrm{ml})$. Stimulation was initiated by directly adding agents prepared in $1.5 \mathrm{ml}$ of fresh culture media (total volume per dish, $14 \mathrm{ml}$ ). To stop the stimulation, we placed dishes on ice and replaced $9 \mathrm{ml}$ of distant media with $5 \mathrm{ml}$ of ice-cold methanol, which fixed the cells plus adjacent media. In some experiments, we fixed the removed $9 \mathrm{ml}$ of distant media by adding it to $9 \mathrm{ml}$ of ice-cold methanol. Lipids from either cells plus adjacent media or distant media were then extracted with chloroform, and endocannabinoids were purified by HPLC and analyzed by chemical ionization gas chromatography/mass spectrometry (CI-GC/MS) as described previously (Stella and Piomelli, 2001; Walter et al., 2002).

Protein content was quantified by using sister cultures (i.e., from the same preparation) grown in $35 \mathrm{~mm}$ culture dishes. To avoid a contamination from the proteins present in Cellgro (e.g., $1 \mathrm{mg} / \mathrm{ml}$ albumin) and B27-supplemented Neurobasal, the entire medium was removed and the cells were rinsed once with PBS. Cells were then lysed with Triton X-100 $(0.1 \%)$ and sonicated, and protein content was quantified with a Bio-Rad (Hercules, CA) Dc Protein Assay.

MAP kinase phosphorylation. BV-2 cells in $100 \mathrm{~mm}$ dishes were incubated and stimulated as described above for the CI-GC/MS analysis. We replaced the media with ice-cold lysis buffer to stop the stimulation. We used Western blotting with monoclonal antibodies that recognize the dual-phosphorylation state of extracellular signal-regulated kinase 1/2 (ERK1/2) on Thr202 and Tyr204 [phospho-p44/42 MAP kinase (MAPK); Cell Signaling Technology, Beverly, MA] to detect activation of MAPK, and polyclonal antibodies against extracellularly regulated kinase 2 (ERK2; Santa Cruz Biotechnology, Santa Cruz, CA) to determine total ERK2, as described previously (Wade et al., 2001). Samples were scanned and analyzed with the NIH Image analysis program.

\section{Results}

It is known that CB1 receptors are widespread in healthy brain, being expressed by many neurons, some astrocytes, and possibly resting microglial cells; however, $\mathrm{CB} 2$ receptors are absent in these cells (Tsou et al., 1998; Waksman et al., 1999; Rodríguez et al., 2001). Because the expression of cannabinoid receptor isoform changes as a result of cell activation, as illustrated with macrophage-like cells (Lee et al., 2001), we hypothesized that activated microglial cells express additional cannabinoid receptor isoforms. To test this hypothesis, we took advantage of the fact 
Table 1. Cannabinoid receptor subtypes

\begin{tabular}{lll}
\hline $\begin{array}{l}\text { Cannabinoid receptor } \\
\text { subtypes }\end{array}$ & Agonists & Antagonists \\
\hline CB1 & THC, AEA, 2-AG & SR141716A \\
CB2 & THC, 2-AG, CBN & SR144528, CBN \\
abn-CBD & AEA, abn-CBD, CBD & $0-1918$, CBD \\
\hline
\end{tabular}

The three subtypes of cannabinoid receptors referred to in this study, with their allied agonists and antagonists. Note that $C B N$ and $C B D$ act as partial agonists at $C B 2$ and abn-CBD receptors, respectively, and therefore also act as antagonists.

that microglial cells are activated when transferred into primary culture (Becher and Antel, 1996), and we used RT-PCR to assess whether these cells contain mRNA encoding for CB1 and/or CB2 receptors. Both cultured mouse microglial cells and BV-2 cells contain CB1 and CB2 receptor mRNA (Fig. 1a,b). Using an antibody that recognizes the $\mathrm{C}$-terminal domain of $\mathrm{CB} 1$ receptors (Hájos et al., 2000), we saw that CB1 receptors were localized primarily in the intracellular compartment of activated microglial cells rather than on their plasma membrane (Fig. 1c,d). To analyze CB2 receptor localization, we generated a rabbit polyclonal antibody specific for the C-terminal domain of CB2 receptors. This antibody labeled HEK293 cells transfected with rat CB2 receptors, whereas no staining was observed when the antibody was preabsorbed with the immunizing peptide or in nontransfected cells (Fig. 1e,f). Using this CB2-specific antibody we found that, unlike CB1 receptors, CB2 receptors were expressed heterogeneously throughout cells, with especially high density at the leading edges of lamellipodia (Fig. $1 g$ ) and microspikes (Fig. 1h), two cellular protrusions that contain polymerized actin filaments and mediate cell migration (Mitchison and Cramer, 1996; Watanabe and Mitchison, 2002).

Cell migration is triggered by chemoattractants that act through seven transmembrane/ $\mathrm{G}_{\mathrm{i} / \mathrm{o}}$-coupled receptors, some of which accumulate at the leading edges of lamellipodia (Servant et al., 1999). Because it is known that THC triggers the migration of macrophages (Schwartzfarb et al., 1974) [possibly by acting through $\mathrm{G}_{\mathrm{i} / \mathrm{o}}$-coupled $\mathrm{CB} 2$ receptors (Derocq et al., 2000)], and because we found that activated microglial cells express CB2 receptors at the leading edges of their motile protrusions (Fig. 1), we sought to determine whether cannabinoids affect microglial cell migration. To address this possibility, we used the Boyden chamber assay (Wilkinson, 1998). BV-2 cells were added to the upper chamber, and their migration through a filter toward a lower chamber containing cannabinoids was quantified. We found that THC had no significant effect on basal BV-2 cell migration at concentrations of $<3 \mu \mathrm{M}$ (Fig. 2a), whereas CBD slightly increased migration with an $\mathrm{EC}_{50}$ of $250 \mathrm{nM}$. Next, we tested the effect of abnormal-cannabidiol, a synthetic agonist that acts as a full agonist on abn-CBD receptors (Járai et al., 1999). Abnormal-cannabidiol significantly increased cell migration with an $\mathrm{EC}_{50}$ of $600 \mathrm{~nm}$ (Fig. 2c). It is important to note that abnormal-cannabidiol and THC acted synergistically when both were added at low nanomolar concentrations (Fig. 2d), which suggests that microglial cell migration is regulated by abn-CBD receptors and cannabinoid receptors (possibly CB2 receptors) acting in a cooperative/synergistic manner.

AEA and 2-arachidonylglycerol (2-AG), two endocannabinoids produced by neurons (Di Marzo et al., 1994; Stella et al., 1997; Stella and Piomelli, 2001), increased BV-2 cell migration in a concentration-dependent manner (Fig. 3a,c), whereas arachidonic acid, a result of the hydrolysis of these lipids, had no effect (data not shown). Two putative endocannabinoids, homo- $\gamma$ linolenylethanolamide (HEA) and docosatetraenylethanolamide
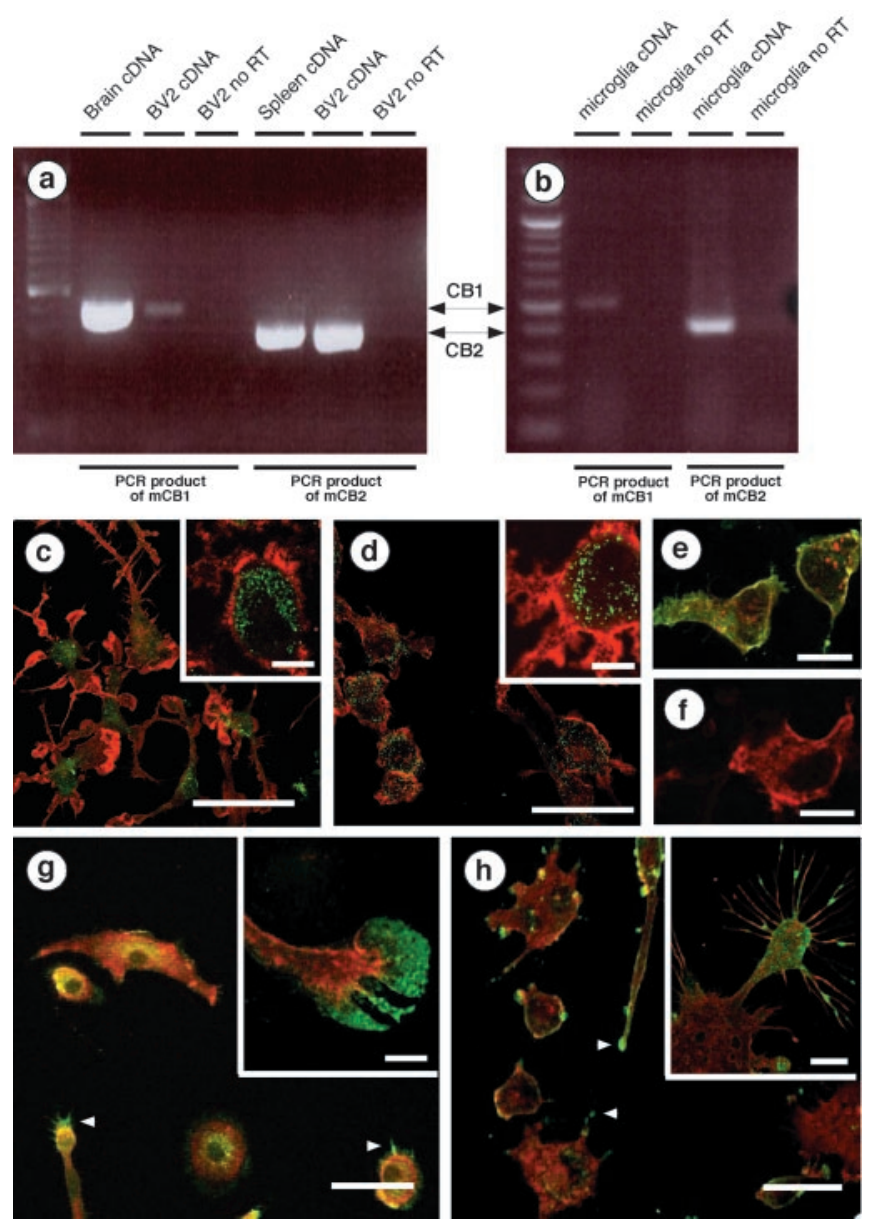

Figure 1. Microglial cells express cannabinoid $C B 1$ and $C B 2$ receptors. $a, b, R T-P C R$ was performed with primers that recognize either mouse $C B 1$ ( $m C B 1)$ or mouse $C B 2$ ( $m C B 2)$ mRNA. We used reverse-transcribed total RNA from mouse brain and spleen (i.e., positive controls), BV-2 cells, and mouse microglial cells. RT-PCR products were of the appropriate size ( $502 \mathrm{bp}$ for CB1 and 401 bp for (B2) and sequence. $c-h$, Immunofluorescent confocal microscopy. Mouse microglial cells $(c)$ and BV-2 cells $(d)$ were stained with an antibody directed against the CB1 C terminus ( green) and phalloidin to label actin (red). Scale bars, $50 \mu \mathrm{m}$. Insets, Higher magnifications of the $C B 1$ receptors ( green) located in the intracellular compartment (MAC1, a plasma membrane macrophage marker, is in red). Scale bars, $10 \mu \mathrm{m}$. e, HEK293 cells transiently transfected with rat $\mathrm{CB} 2$ receptors tagged with $\mathrm{HA11}$ (red) and stained with antibodies directed against CB2 C terminus ( green). Colocalization is yellow. $f$, Similar immunostaining as in e, but performed in the presence of the immunizing antigen (i.e., the last 42 aa of the mouse CB2 receptor ( terminus). Scale bars, $35 \mu \mathrm{m}$. Mouse microglial cells $(g)$ and BV-2 cells $(h)$ stained with antibodies directed against the CB2 receptor C terminus ( green) and phalloidin (red). Arrowheads indicate CB2 receptors located at the lamellipodia tip. Scale bars, $50 \mu \mathrm{m}$. Insets, Higher magnification showing CB2 receptors at the leading edges of lamellipodia $(g)$ and on microspikes $(h)$. Scale bars, $10 \mu \mathrm{m}$.

(DEA) (Felder et al., 1993; Hanus et al., 1993; Pertwee et al., 1994), also increased BV-2 cell migration in a concentrationdependent manner (Fig. 3e,f), whereas palmitylethanolamide (PEA), which is a congener of AEA that does not act on CB1 or CB2 receptors (Griffin et al., 2000), had no effect (Fig. $3 d$ ). It is noteworthy that AEA, 2-AG, HEA, and DEA at $1 \mu \mathrm{M}$ appear to act through the same receptors and/or signal transduction pathway, because their effects were not additive (data not shown).

Because 2-AG triggers microglial cell migration with the highest potency and efficacy, we also characterized its effect. Cell motility can be divided into (1) basal random motion, which occurs in the absence of a stimulus, (2) chemokinesis, which is random motion increased by a chemical stimulus, and (3) chemotaxis, 

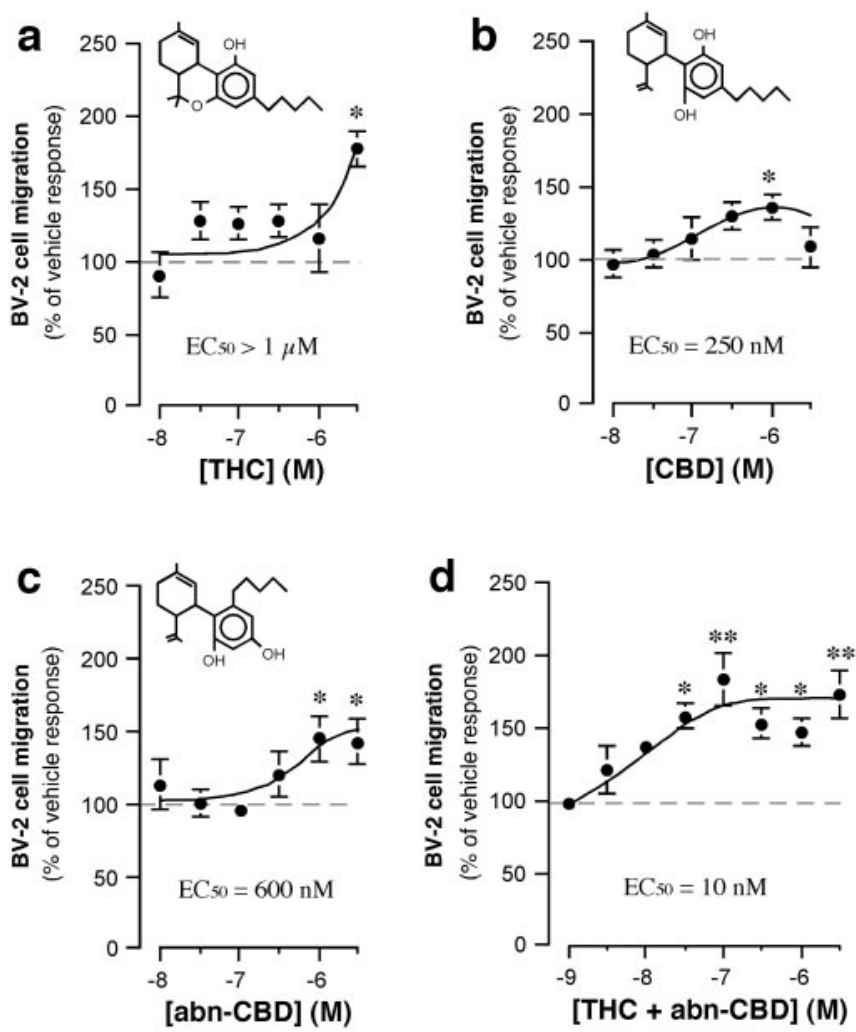

Figure 2. Cannabinoids increase microglial cell migration. $a-d$, In the lower chamber of the Boyden chamber assay, we added THC $(a), \mathrm{CBD}(b)$, abn-CBD $(c)$, and THC plus abn-CBD ( $d)$ (at a 1:1 molar ratio). BV-2 cell migration toward these ligands was quantified, and results are expressed as a percentage of basal BV-2 cell migration (i.e., vehicle $=0.1 \%$ DMS0; dashed line) measured in individual experiments. ${ }^{*} p<0.05$; ${ }^{* *} p<0.01$; significantly different from basal BV-2 cell migration (ANOVA followed by Dunnett's post hoc test). Values are mean \pm SEM of 9-45 independent quantifications of migration (i.e., 3-15 separate experiments performed in triplicate).

which is directed cell migration along a chemical gradient (Wilkinson, 1998). To determine whether 2-AG triggers chemokinesis, chemotaxis, or a combination of both, we performed a checkerboard experiment in which equal concentrations of $2-\mathrm{AG}$ were added to both the upper and the lower chambers, thereby disrupting the chemical gradient, and followed BV-2 cell migration under these conditions. If $2-\mathrm{AG}$ produces chemokinesis, the response should persist in this disrupted gradient. If 2-AG produces chemotaxis, the response should be absent. We found that the 2-AG-triggered microglial cell migration was reduced by $50 \%$ when performing the checkerboard experiments, indicating that $2-\mathrm{AG}$ induces both chemokinesis and chemotaxis $(n=3)$.

Figure $4, a$ and $b$, shows that 2-AG-triggered migration was prevented by (1) pertussis toxin pretreatment, which uncouples $\mathrm{G}_{\mathrm{i} / \mathrm{o}}$-coupled receptors; (2) $\mathrm{N}$-(1,S)-endo1,3,3-trimethylbicyclo$(2,2,1)$ heptan-2-yl)-5(4-chloro-3-methyl-phenyl)-1-(4-methylbenzyl)-pyrazole-3-carboxamide (SR144528), a CB2 receptor antagonist (Rinaldi-Carmona et al., 1998); (3) CBN, a CB2 receptor partial agonist (Felder et al., 1995); (4) O-1918, an abn-CBD receptor antagonist (G. Kunos, unpublished observations); and (5) CBD, an abn-CBD receptor partial agonist (Járai et al., 1999). These results indicate that 2-AG triggers microglial cell migration by acting through $\mathrm{G}_{\mathrm{i} / \mathrm{o}}$-coupled $\mathrm{CB} 2$ and abn-CBD receptors. The 2-AG response did not involve $\mathrm{CB} 1$ receptors, because $N$-(piperidiny-1-yl)5-(4-chlorophenyl)-1-(2,4-dichlorophenyl)-4-methyl-1H-pyrazole -3-carboxamide (SR141716A), a CB1 receptor antagonist (Rinaldi-
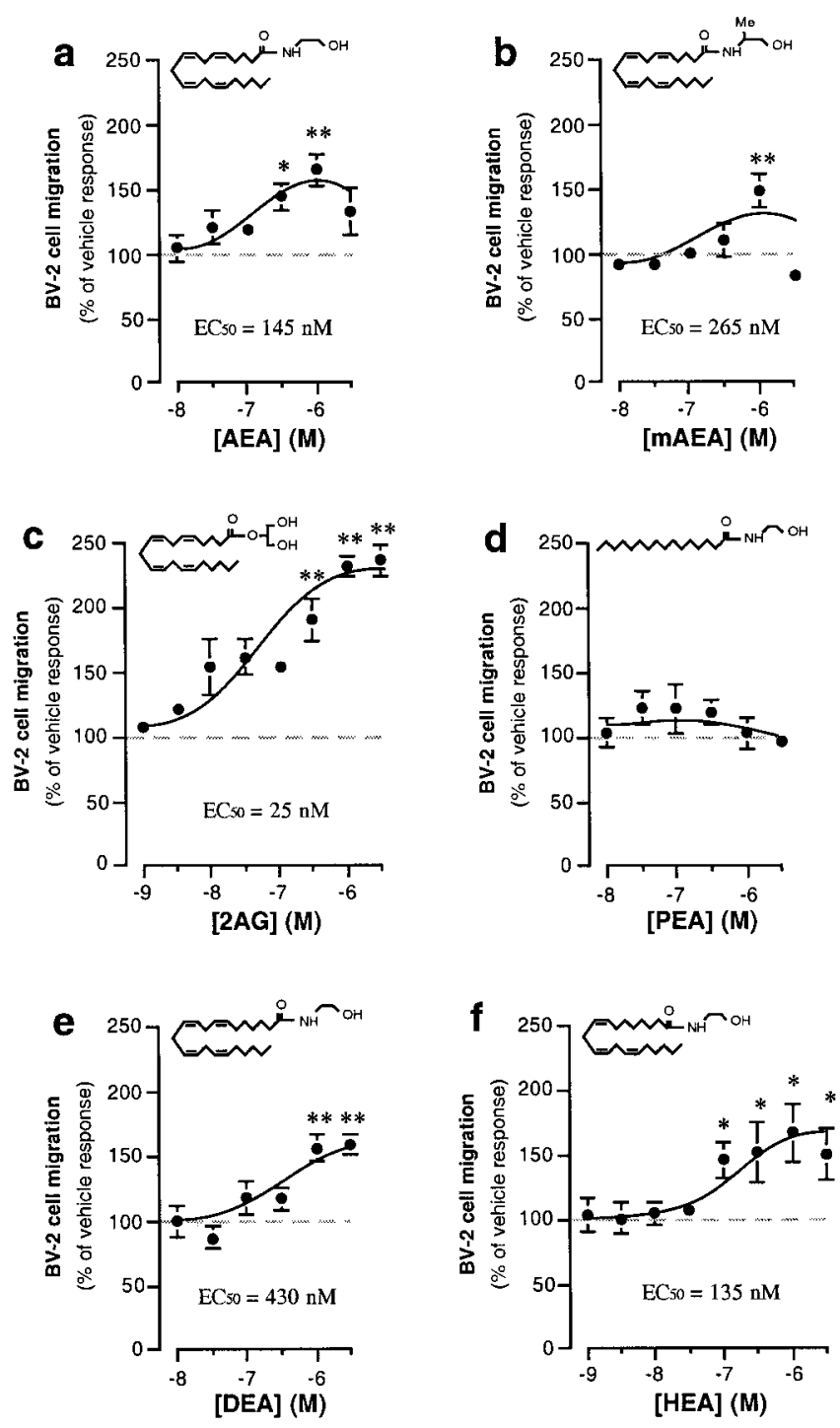

Figure 3. Endocannabinoids increase microglial cell migration. $a-f$, In the lower chamber of the Boyden chamber assay, we added AEA ( $a$ ), meth-AEA (mAEA; $b), 2-A G(2 A G ; c), \operatorname{PEA}(d)$, DEA $(e)$, and HEA $(f)$. BV-2 cell migration toward these ligands was quantified, and results are expressed as a percentage of basal BV-2 cell migration (i.e., vehicle $=0.1 \%$ DMSO; dashed line) measured in individual experiments. ${ }^{*} p<0.05$; ${ }^{* *} p<0.01$; significantly different from basal BV-2 cell migration (ANOVA followed by Dunnett's post hoc test). Values are mean \pm SEM of $9-45$ independent quantifications of migration (i.e., 3-15 separate experiments performed in triplicate).

Carmona et al., 1994), did not decrease migration significantly (Fig. $4 a, b)$; the response also was not mimicked by $100 \mathrm{~nm}$ methanandamide (meth-AEA), a CB1/CB2 receptor agonist (Fig. $3 b$ ). Note that $1 \mu \mathrm{M}$ methanandamide significantly increased BV-2 cell migration, likely because of its agonist effect on CB2 receptors (Goutopoulos et al., 2001).

CB2 receptors activate ERK1/2 (Bouaboula et al., 1996), a signal transduction pathway known to regulate cell migration (Klemke et al., 1997). Therefore, we assessed whether the 2-AG response requires this signal transduction pathway. Indeed, 2-AG increased ERK1/2 activity in BV-2 cells (Fig. $4 c, d$ ), and an inhibitor of this pathway, PD98059, abolished the 2-AG-triggered BV-2 cell migration (Fig. 4a,b).

In the second part of our study, we assessed whether pathological stimuli affect endocannabinoid production, because this 

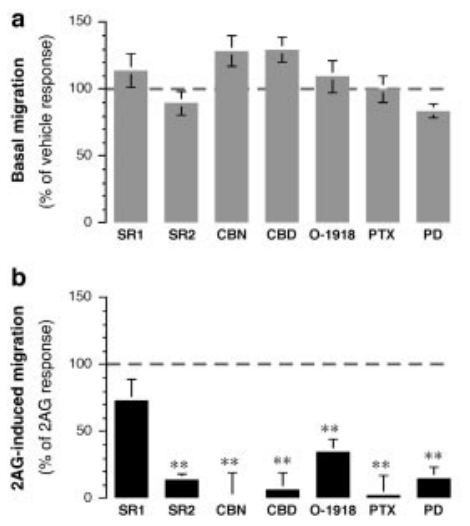

c
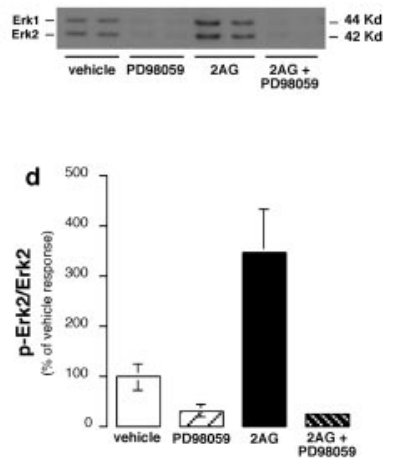

Figure 4. 2-AG increases microglial cell migration by acting through CB2- and CBD-sensitive receptors and stimulating ERK1/2 activity. $a$, Effects of various agents on basal migration. Values in $a$ and $b$ are means \pm SEM of $9-36$ independent quantifications of migration (i.e., 3-12 separate experiments performed in triplicate). Agents that were added to the lower chamber are as follows: 30 nм SR141716A (SR1), 30 nм SR144528 (SR2), 300 nм CBN, 300 nм CBD, $1 \mu \mathrm{m}$ 0-1918, or $10 \mu \mathrm{m}$ PD98059 (PD). To test for the involvement of $\mathrm{G}_{\mathrm{i} / 0}$-proteins, BV-2 cells were pretreated with $1 \mu \mathrm{g} / \mathrm{ml}$ pertussis toxin (PTX) for $18 \mathrm{hr}$. $b$, Effects of various agents on 2-AG (2AG)-induced migration. Results are expressed as a percentage of the control 2-AG-induced migration determined in each experiment (i.e., migration induced by $1 \mu \mathrm{m} 2-\mathrm{AG}$ added alone to the lower chamber minus corresponding basal migration obtained with the same agent; dashed line; see $a) .{ }^{*} p<0.05 ;{ }^{* *} p<0.01$; significantly different from the control 2-AG response (Student's $t$ test). c, Representative Western blot with phospho-ERK1/2 antibodies. $d$, Quantification of three separate experiments performed in duplicate $(n=6) .{ }^{* *} p<0.01$; significantly different from basal (ANOVA followed by Dunnett's post hoc test).

could participate in recruiting microglial cells to the lesion site. First, we investigated how the neuronal production of AEA, 2-AG, HEA, and DEA is affected by acute challenge with (1) ionomycin, a calcium ionophore that induces large increases in intracellular calcium, and (2) glutamate plus carbachol, which mimics pathological overstimulation (Stella and Piomelli, 2001). To our knowledge, HEA and DEA production by neurons has never been documented. Acute stimulation of neurons with ionomycin for 2.5 min selectively increased HEA and DEA production (Fig. $5 a-d$ ), whereas it had no effect on AEA and 2-AG production, which is consistent with reports showing that only longer applications of ionomycin (e.g., $20 \mathrm{~min}$ ) increase AEA and 2-AG production (Di Marzo et al., 1994; Stella et al., 1997). Glutamate plus carbachol applied for $2.5 \mathrm{~min}$ dramatically increased the production of 2-AG, modestly increased the production of AEA and DEA, and did not affect HEA production (Fig. $5 a-d$ ). These results show that the ionomycin-induced increase in intracellular calcium or the pathological stimulation of neurons enhances the production of different endocannabinoids, with 2-AG being the most abundant endocannabinoid produced under pathological conditions.

We then determined whether microglial cells produce endocannabinoids, because (1) this has never been addressed directly, (2) it is known that macrophages produce these ligands in a calcium-dependent manner (Wagner et al., 1997; Schmid et al., 2000), and (3) endocannabinoid produced by microglial cells could participate in recruiting more distant microglial cells toward dying neurons. Ionomycin increased 2-AG and DEA production from BV-2 cells, whereas AEA and HEA production was unaffected (Fig. $5 a-d$ ). Chelation of extracellular calcium with EGTA prevented this response. We found that under basal conditions mouse microglial cells in culture contained higher amounts of endocannabinoids than neurons in culture (Table 2). Like BV-2 cells, ionomycin increased the production of 2-AG and
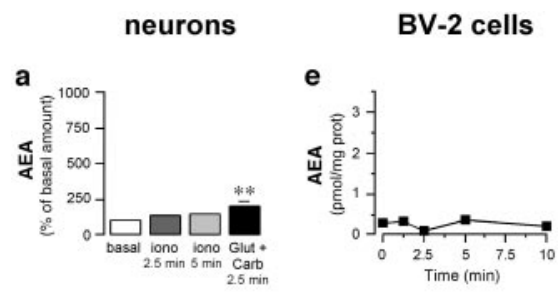

microglial cells

i

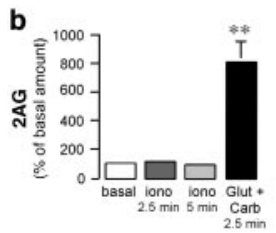

f
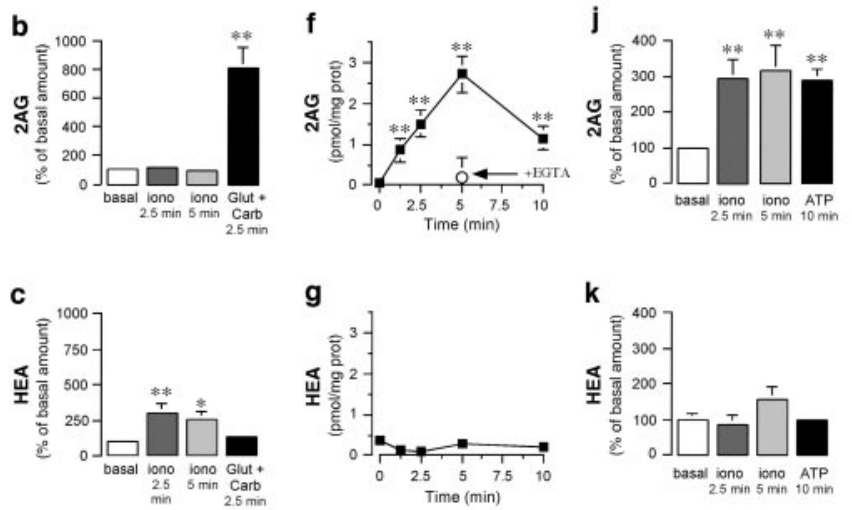

g

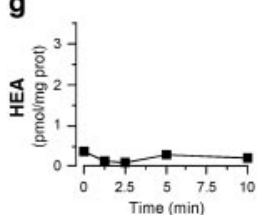

k
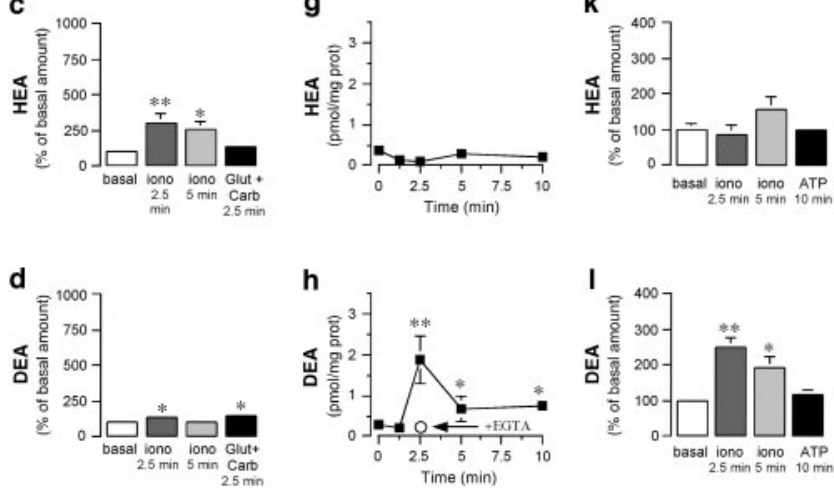

h
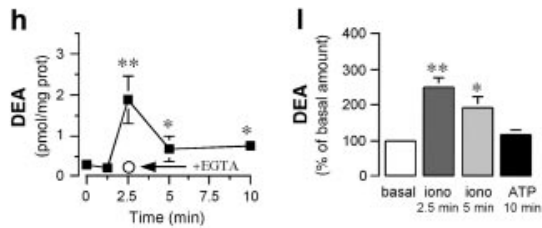

Figure 5. Mouse neurons and microglial cells produce four endocannabinoids. $a-d$, Mouse neurons were incubated with ionomycin (iono; $5 \mu \mathrm{m}$ ) for 2.5 and 5 min or with glutamate ( $G l u t$; $100 \mu \mathrm{M})$ and carbachol (Carb; $1 \mathrm{~mm}$ ) for $2.5 \mathrm{~min}$, lipids were extracted from chloroform from cells plus adjacent media and purified by HPLC; AEA ( $a), 2-\operatorname{AG}(2 A G ; b), \operatorname{HEA}(c)$, and DEA (d) were then quantified by $\mathrm{CI}-\mathrm{GC} / \mathrm{MS}$. $e-h$, BV-2 cells were incubated with ionomycin $(5 \mu \mathrm{m})$ for increasing periods of time, and endocannabinoids were quantified. prot, Protein. The arrow indicates that EGTA (5 mM) prevents the ionomycin response. $i-I$, Mouse microglial cells were incubated with ionomycin $(5 \mu \mathrm{m})$ for 2.5 and $5 \mathrm{~min}$ or with ATP $(1 \mathrm{mM})$ for $10 \mathrm{~min}$, and endocannabinoids were quantified. Values are means \pm SEM of $6-32$ independent endocannabinoid quantifications, each performed on one $100 \mathrm{~mm}$ dish of cells. ${ }^{*} p<0.05$; ${ }^{* *} p<0.01$; significantly different from basal amount (see Table 1) (ANOVA followed by Dunnett's post hoc test).

DEA from mouse microglial cells without affecting AEA and HEA (Fig. $5 e-h)$. It is important to note that ATP selectively increased 2-AG production from mouse microglial cells (Fig. 5eh). These results show that the production of 2-AG and DEA from microglial cells can be increased, although only 2-AG production is increased by a pathological stimulus.

Finally, we determined whether endocannabinoids produced by microglial cells are released, because a paracrine function for

Table 2. Endocannabinoid contents in primary cultures of mouse neurons and microglial cells under basal conditions

\begin{tabular}{llc}
\hline & \multicolumn{2}{l}{ Endocannabinoid content } \\
\cline { 2 - 3 } & $\begin{array}{l}\text { Neurons } \\
\text { (pmol/mg protein) }\end{array}$ & $\begin{array}{l}\text { Microglial cells } \\
\text { (pmol/mg protein) }\end{array}$ \\
\hline AEA & $0.7 \pm 0.2$ & $13.6 \pm 4.3$ \\
2-AG & $0.4 \pm 0.1$ & $8.2 \pm 2.0$ \\
HEA & $0.2 \pm 0.1$ & $1.7 \pm 0.4$ \\
DEA & $0.4 \pm 0.1$ & $4.1 \pm 1.1$
\end{tabular}

Mouse neurons and microglial cells cultured in $100 \mathrm{~mm}$ dishes contained $4.15 \pm 0.2$ and $0.55 \pm 0.04 \mathrm{mg}$ of protein per dish, respectively $(n=14)$. Cells were analyzed under basal conditions (i.e., in cell culture media); endocannabinoids were extracted from cells plus adjacent media, purified by HPLC, and quantified by CI-GC/MS. Values are mean \pm SEM of 14 independent quantifications of endocannabinoids, each performed on one $100 \mathrm{~mm}$ dish of cells. 
these lipids has been suggested in neuronal signaling (Bisogno et al., 1997; Giuffrida et al., 1999; Kreitzer and Regehr, 2001; Wilson and Nicoll, 2001). To do this, we used BV-2 cells that either were kept under basal condition or were stimulated with ionomycin for $5 \mathrm{~min}$ and assessed the relative amount of endocannabinoids present in (1) cells plus adjacent media and (2) distant media. We found that $60 \%$ of total AEA and 54\% of total HEA was released toward distant media under both basal and ionomycinstimulated conditions $(n=10$ independent endocannabinoid quantifications, each performed on cells contained in one 100 $\mathrm{mm}$ dish). Under basal conditions, 2-AG was undetectable in cells plus adjacent media, as well as in distant media, whereas after ionomycin stimulation, $36 \%$ of $2-\mathrm{AG}$ was released toward distant media. It is interesting to note that under basal conditions, 59\% of DEA was released toward distant media, whereas after ionomycin stimulation, only $34 \%$ of DEA was released toward distant media. These results indicate that a portion of endocannabinoids produced by microglial cells is released from cells toward distant media, reinforcing the notion that these lipids serve a paracrine signaling function. Additionally, our results indicate that the relative amount of endocannabinoid that is released toward distant media varies depending on endocannabinoid subtype and whether cells are acutely stimulated.

\section{Discussion}

Many of the signaling molecules in the body (e.g., eicosanoids) are present not as single entities but as large families of structurally related substances. In 1992, when Devane et al. identified AEA as a ligand for CB1 receptors, it seemed reasonable to expect that this lipid was only the first representative of a larger family of endocannabinoids (Devane et al., 1992). Indeed, ensuing studies identified a second endocannabinoid, 2-AG, that acts as a full agonist on CB1 and CB2 receptors (Mechoulam et al., 1995; Sugiura et al., 1995, 2000; Stella et al., 1997). In this study, we show that neurons and microglial cells produce four endocannabinoids: the two well known endocannabinoids, AEA and 2-AG, as well as the two new endocannabinoids, HEA and DEA. It is interesting to note that astrocytes in culture also produce these four endocannabinoids (Walter et al., 2002) (L. Walter and N. Stella, unpublished observations). Thus, the endocannabinoid family contains several structurally related lipids that are produced in the CNS by neurons, microglial cells, and astrocytes. It should be emphasized that microglial cells produce $\sim 20$-fold higher amounts of endocannabinoids (expressed in picomoles per nanogram of protein) compared with neurons and astrocytes. On the basis of these data, we propose that, during neuroinflammation, activated microglial cells produce the majority of endocannabinoids that accumulate at the lesion site. A recent study identified yet an additional endocannabinoid in the brain (i.e., noladin) that is an analog of 2-AG that acts on CB1 receptors (Hanus et al., 2001). However, studies that address the cellular source of this lipid, as well as its pathway of biosynthesis, remain to be performed.

The presence of a large family of endocannabinoids leaves open many questions. What are the physiological and pathological stimuli that increase endocannabinoid production? Can different stimuli selectively increase the production of different endocannabinoids? Does each endocannabinoid have distinct biological functions? We show that glutamate plus carbachol stimulation dramatically increases $2-\mathrm{AG}$ production from neurons. Under these conditions, AEA and DEA production is increased only slightly, whereas HEA production is unchanged. It is important to note that HEA and DEA production from neurons is increased by acute application of ionomycin, which shows that the production of these two endocannabinoid candidates is indeed calcium dependent. This result reinforces the notion that different pathways of biosynthesis of endocannabinoids exist in neurons, and that their selective production is driven by specific stimuli (Stella et al., 1997; Giuffrida et al., 1999; Stella and Piomelli, 2001). The same idea holds true for microglial cells and astrocytes. ATP increases the production of 2-AG from microglial cells without affecting the production of AEA, HEA, or DEA. We have shown recently that, in cultured astrocytes, endothelin, a peptide produced by endothelial cells during stroke, increases 2-AG production fivefold and AEA production twofold, whereas it does not affect HEA and DEA production (Walter et al., 2002) (Walter and Stella, unpublished observations). In summary, 2-AG production is dramatically increased by three pathological stimuli that affect neurons, microglial cells, or astrocytes, a finding that corroborates the observed increase in this particular endocannabinoid during neuroinflammation induced in vivo (Baker et al., 2001; Panikashvili et al., 2001).

We present evidence that 2-AG recruits microglial cells by engaging $\mathrm{CB} 2$ and abn-CBD receptors. To our knowledge, this is the first study to report that $2-\mathrm{AG}$ is a full agonist at abn-CBD receptors. We ruled out the involvement of $\mathrm{CB} 1$ receptors in the 2-AG-triggered microglial cell migration because this response was not antagonized by $30 \mathrm{nM}$ SR141716A, a concentration that antagonizes $\mathrm{CB} 1$ receptors $\left(\mathrm{IC}_{50}=5 \mathrm{nM}\right)$ without affecting abnCBD receptors $\left(\mathrm{IC}_{50}=600 \mathrm{nM}\right)$ (Jung et al., 1997; Bukoski et al., 2002). Additionally, we show that THC and abnormalcannabidiol induce a synergistic increase in microglial cell migration. Although the molecular basis of this synergistic response remains unknown, our results show that engagement of both $\mathrm{CB} 2$ and abn-CBD receptors is required to trigger microglial cell migration.

Although both CB1 and CB2 receptors are expressed in activated microglial cells, their cellular location is quite different. This suggests that the functionality of either receptor might be regulated by translocation to the plasma membrane. Changes in the cellular location of cannabinoid receptors that are associated with a change in their functionality have been described with CB2 receptors in transfected cells (Bouaboula et al., 1999). The dynamics of cannabinoid receptor movement between cellular compartments during microglial cell activation, for example, during migration, is a key question. Indeed, studies performed with different G-protein-coupled receptors, namely the complement C5a receptors, propose that these types of receptors accumulate at the leading edges of lamellipodia as a result of plasma membrane accumulation (Servant et al., 1999). Using a CB2 receptor antibody, we show that $\mathrm{CB} 2$ receptors are abundant at the leading edges of activated microglial cells, as well as at the microspikes of BV-2 cells. Whether accumulation of CB2 receptors at the leading edges of these protrusions is caused by accumulation of membranes or by a true increase in receptor density is unknown.

Because we found that 2-AG triggers microglial cell migration with high potency and efficacy, we hypothesize that this particular endocannabinoid participates in recruiting microglial cells toward neuroinflammatory lesion sites. The following model can be put forward. First, pathological overstimulation of neurons, which eventually results in their death, increases $2-A G$ production and recruits surrounding microglial cells. Once these microglial cells arrive at the lesion site, ATP, which is released by dying neurons, acts on the headmost microglial cells, further increasing local 2-AG and further recruiting microglial cells. Such a model is reminiscent of many feed- 
forward mechanisms that lead to local recruitment of immune cells and amplification of inflammation. We also show that CBN and $\mathrm{CBD}$, two nonpsychotropic bioactive compounds of marijuana (Perez-Reyes et al., 1973), may antagonize the 2-AG-induced recruitment of microglial cells. This is in agreement with the fact that nabilone, a synthetic analog of THC, produces minimal palliative effects against multiple sclerosis symptoms, whereas smoking cannabis is reported to be beneficial (Martyn et al., 1995; Consroe et al., 1997). Therefore, our results suggest that bioactive cannabinoids present in the marijuana plant, such as CBN and CBD, are likely to underlie the increased efficacy of cannabis versus nabilone and therefore hold promise as nonpsychotropic therapeutics to treat neuroinflammation.

\section{References}

Baker D, Pryce G, Croxford LJ, Brown P, Pertwee RG, Huffman JW, Layward L (2000) Cannabinoids control spasticity and tremor in a multiple sclerosis model. Nature 404:84-87.

Baker D, Pryce G, Croxford LJ, Brown P, Pertwee RG, Makriyannis A, Knanolkar A, Layward L, Fezza F, Bisogno T, DiMarzo V (2001) Endocannabinoids control spasticity in a multiple sclerosis model. FASEB J 15:300-302.

Becher B, Antel JP (1996) Comparison of phenotypic and functional properties of immediately ex vivo and cultured human adult microglia. Glia 18:1-10.

Becher B, Prat A, Antel JP (2000) Brain-immune connection: immunoregulatory properties of CNS-resident cells. Glia 29:293-304.

Bisogno T, Sepe N, Melck D, Maurelli S, De Petrocellis L, Di Marzo V (1997) Biosynthesis, release and degradation of the novel endogenous cannabimimetic metabolite 2-arachidonoylglycerol in mouse neuroblastoma cells. Biochem J 322:671-677.

Bouaboula M, Poinot-Chazel C, Marchand J, Canat X, Bourrié B, RinaldiCarmona M, Calandra B, Le Fur G, Casellas P (1996) Signaling pathway associated with stimulation of CB2 peripheral cannabinoid receptor. Eur J Biochem 237:704-711.

Bouaboula M, Dussossoy D, Casellas P (1999) Regulation of peripheral cannabinoid receptor CB2 phosphorylation by the inverse agonist SR144528. J Biol Chem 274:20397-20405.

Bruce-Keller AJ (1999) Microglial-neuronal interactions in synaptic damage and recovery. J Neurosci Res 58:191-201.

Buckley NE, McCoy KL, Mezey E, Bonner T, Zimmer A, Felder CC, Glass M, Zimmer A (2000) Immunomodulation by cannabinoids is absent in mice deficient for the cannabinoid CB2 receptor. Eur J Pharmacol 396:141-149.

Bukoski RD, Bátkai S, Járai Z, Wang Y, Offertaler L, Jackson WF, Kunos G (2002) CB1 receptor antagonist SR141617A inhibits $\mathrm{Ca}^{2+}$-induced relaxation in CB1 receptor-deficient mice. Hypotension 39:251-257.

Consroe P, Musty R, Rein J, Tillery W, Pertwee R (1997) The perceived effects of smoked cannabis on patients with multiple sclerosis. Eur Neurol 38:44-48.

Derocq J-M, Jbilo O, Bouaboula M, Ségui M, Clère C, Casellas P (2000) Genomic and functional changes induced by the activation of the peripheral cannabinoid receptor CB2 in the promyelocytic cells HL-60. J Biol Chem 275:15621-15628.

Devane WA, Hanus L, Breuer A, Pertwee RG, Stevenson LA, Griffin G, Gibson D, Mandelbaum A, Etinger A, Mechoulam R (1992) Isolation and structure of a brain constituent that binds to the cannabinoid receptor. Science 258:1946-1949.

Di Marzo V, Fontana A, Cadas H, Schinelli S, Cimino G, Schwartz J-C, Piomelli D (1994) Formation and inactivation of endogenous cannabinoid anandamide in central neurons. Nature 372:686-691.

Felder CC, Briley EM, Axelrod J, Simpson JT, Mackie K, Devane WA (1993) Anandamide, an endogenous cannabimimetic eicosanoid, binds to the cloned human cannabinoid receptor and stimulates receptor-mediated signal transduction. Proc Natl Acad Sci USA 90:7656-7660.

Felder CC, Joyce KE, Briley EM, Mansouri J, Mackie K, Blond O, Lai Y, Ma AL, Mitchell RL (1995) Comparison of the pharmacology and signal transduction of the human cannabinoid CB1 and CB2 receptors. Mol Pharmacol 48:443-450.

Giuffrida A, Parsons LH, Kerr TM, Rodríguez de Fonseca F, Navarro M,
Piomelli D (1999) Dopamine activation of endogenous cannabinoid signalling in dorsal striatum. Nat Neurosci 2:358-363.

Goutopoulos A, Fan P, Khanolkar AD, Xie X-Q, Lin S, Makriyannis A (2001) Stereochemical selectivity of methanandamides for the CB1 and CB2 cannabinoid receptors and their metabolic stability. Bioorg Med Chem 9:1673-1684.

Griffin G, Tao Q, Abood ME (2000) Cloning and pharmacological characterization of the rat CB2 cannabinoid receptor. J Pharmacol Exp Ther 292:886-894

Hájos N, Katona I, Naiem SS, Mackie K, Ledent C, Mody I, Freund TF (2000) Cannabinoids inhibit hippocampal GABAergic transmission and network oscillations. Eur J Neurosci 12:3239-3249.

Hall W, Solowij N (1998) Adverse effects of cannabis. Lancet 352:1611-1616.

Hampson RE, Deadwyler SA (2000) Cannabinoids reveal the necessity of hippocampal neural encoding for short-term memory in rats. J Neurosci $20: 8932-8942$.

Hanus L, Gopher A, Almog S, Mechoulam R (1993) Two new unsaturated fatty acid ethanolamides in brain that bind to the cannabinoid receptor. J Med Chem 36:3032-3034.

Hanus L, Abu-Lafi S, Fride E, Breuer A, Vogel Z, Shalev DE, Kustanovich I, Mechoulam R (2001) 2-Arachidonyl glyceryl ether, an endogenous agonist of the cannabinoid CB1 receptor. Proc Natl Acad Sci USA 98:3662-3665.

Howlett AC, Barth F, Bonner TI, Cabral G, Casellas P, Devane WA, Felder CC, Herkenham M, Mackie K, Martin BR, Mechoulam R, Pertwee RG (2002) Classification of cannabinoid receptors. Pharmacol Rev 54:161-202.

Huestis MA, Gorelick DA, Heishman SJ, Preston KL, Nelson RA, Moolchan ET, Frank RA (2001) Blockade of effects of smoked marijuana by the CBl-selective cannabinoid receptor antagonist SR141716. Arch Gen Psychiatry 58:322-328.

Járai Z, Wagner JA, Varga K, Lake KD, Compton DR, Martin BR, Zimmer AM, Bonner TI, Buckley NE, Mezey E, Razdan RK, Zimmer A, Kunos G (1999) Cannabinoid-induced mesenteric vasodilation through an endothelial site distinct from CB1 or CB2 receptors. Proc Natl Acad Sci USA 96:14136-14141.

Jung M, Calassi R, Rinaldi-Carmona M, Chardenot P, Le Fur G, Soubrié P, Oury-Donat F (1997) Characterization of CB1 receptors on rat neuronal cell cultures: binding and functional studies using the selective receptor antagonist SR 141716A. J Neurochem 68:402-409.

Kaminski NE (1998) Regulation of the cAMP cascade, gene expression and immune function by cannabinoid receptors. J Neuroimmunol 83:124-132.

Kim M, Spelta V, Sim J, North AR, Surprenant A (2001) Differential assembly of rat purinergic P2X7 receptor in immune cells of the brain and periphery. J Biol Chem 276:23262-23267.

Klein TW, Friedman H, Specter S (1998) Marijuana, immunity and infection. J Neuroimmunol 83:102-115.

Klemke RL, Cai S, Giannini AL, Gallagher PJ, de Lanerolle P, Cheresh DA (1997) Regulation of cell motility by mitogen-activated protein kinase. J Cell Biol 137:481-492.

Kreitzer AC, Regehr WG (2001) Retrograde inhibition of presynaptic calcium influx by endogenous cannabinoids at excitatory synapses onto Purkinje cells. Neuron 29:717-727.

Kreutzberg GW (1996) Microglia: a sensor for pathological events in the CNS. Trends Neurosci 19:312-318.

Lee SF, Newton C, Widen R, Friedman H, Klein TW (2001) Differential expression of cannabinoid CB2 receptor mRNA in mouse immune cell subpopulation and following B cell stimulation. Eur J Pharmacol 423:235-241.

Lyman WD, Sonett JR, Brosnan CF, Elkin R, Bornstein MB (1989) $\Delta$ 9-Tetrahydrocannabinol: a novel treatment for experimental autoimmune encephalomyelitis. J Neuroimmunol 23:73-81.

Malfait AM, Gallily R, Sumariwalla PF, Malik AS, Andreakos E, Mechoulam R, Feldmann M (2000) The nonpsychoactive cannabis constituent cannabidiol is an oral anti-arthritic therapeutic in murine collagen-induced arthritis. Proc Natl Acad Sci USA 97:9561-9566.

Mallet PE, Beninger RJ (1998) The cannabinoid CB1 receptor antagonist SR141716A attenuates the memory impairment produced by $\Delta^{9}$ tetrahydrocannabinol or anandamide. Psychopharmacology 140:11-19.

Martyn CN, Illis LS, Thom J (1995) Nabilone in the treatment of multiple sclerosis. Lancet 345:579. 
Matsuda LA, Lolait SJ, Brownstein MJ, Young AC, Bonner TI (1990) Structure of a cannabinoid receptor and functional expression of the cloned cDNA. Nature 346:561-564.

Mechoulam R, Ben-Shabat S, Hanus L, Ligumsky M, Kaminski NE, Schatz AR, Gopher A, Almog S, Martin BR, Compton DR, Pertwee RG, Griffin G, Bayewitch M, Barg J, Vogel Z (1995) Identification of an endogenous 2-monoglyceride, present in canine gut, that binds to cannabinoid receptors. Biochem Pharmacol 50:83-90.

Meinck H-M, Schönle PW, Conrad B (1989) Effect of cannabinoids on spasticity and ataxia in multiple sclerosis. J Neurol 236:120-122.

Mitchison TJ, Cramer LP (1996) Actin-based cell motility and cell locomotion. Cell 84:371-379.

Möller T, Kann O, Verkhratsky A, Kettenmann H (2000) Activation of mouse microglial cells affects P2 receptor signaling. Brain Res 853:49-59.

Munro S, Thomas KL, Abu-Shaar M (1993) Molecular characterization of a peripheral receptor for cannabinoids. Nature 365:61-65.

Panikashvili D, Simeonidou C, Ben-Shabat S, Hanus L, Breuer A, Mechoulam $\mathrm{R}$, Shohami E (2001) An endogenous cannabinoid (2-AG) is neuroprotective after brain injury. Nature 413:527-531.

Perez-Reyes M, Timmons MC, Davis KH, Wall ME (1973) A comparison of the pharmacological activity in man of intravenously administered $\Delta^{9}$ tetrahydrocannabinol, cannabinol, and cannabidiol. Experientia (Basel) 29:1368-1369.

Pertwee R, Griffen G, Hanus L, Mechoulam R (1994) Effects of two fatty acid ethanoloamides on mouse vasa deferentia. Eur J Pharmacol 259:115-120

Piomelli D, Beltramo M, Giuffrida A, Stella N (1998) Endogenous cannabinoid signaling. Neurobiol Dis 5:462-473.

Rezaie P, Male D (1999) Colonisation of the developing human brain and spinal cord by microglia: a review. Microscopy Res Tech 45:359-382.

Rinaldi-Carmona M, Barth F, Héaulme M, Shire D, Calandra B, Congy C, Martinez S, Maruani J, Néliat G, Caput D, Ferrara P, Soubrié P, Brelière JC, Le Fur G (1994) SR141716A, a potent and selective antagonist of the brain cannabinoid receptor. FEBS Lett 350:240-244.

Rinaldi-Carmona M, Barth F, Millan J, Derocq J-M, Casellas P, Congy C, Oustric D, Sarran M, Bouaboula M, Calandra B, Portier M, Shire D, Brelière J-C, Le Fur G (1998) SR 144528, the first potent and selective antagonist of the CB2 cannabinoid receptor. J Pharmacol Exp Ther 284:644-650

Rodríguez JJ, Mackie K, Pickel VM (2001) Ultrastructural localization of the $\mathrm{CB} 1$ cannabinoid receptor in $\mu$-opioid receptor patches of the rat caudate putamen nucleus. J Neurosci 21:823-833.

Schmid PC, Schwartz KD, Smith CN, Krebsbach RJ, Berdyshev EV, Schmid HHO (2000) A sensitive endocannabinoid assay: the simultaneous analysis of $N$-acylethanolamines and 2-monoacylglycerols. Chem Phys Lipids 104:185-191

Schwartzfarb L, Needle M, Chavez-Chase M (1974) Dose-related inhibition of leukocyte migration by marijuana and delta-9-tetrahydrocannabinol (THC) in vitro. J Clin Pharmacol 1:35-41.

Servant G, Weiner OD, Neptune ER, Sedat JW, Bourne HR (1999) Dynamics of a chemoattractant receptor in living neutrophils during chemotaxis. Mol Biol Cell 10:1163-1178.
Showalter VM, Compton DR, Martin BR, Abood ME (1996) Evaluation of binding in a transfected cell line expressing a peripheral cannabinoid receptor (CB2): identification of cannabinoid receptor subtype selective ligands. J Pharmacol Exp Ther 278:989-999.

Solowij N, Stephens RS, Roffman RA, Babor T, Kadden R, Miller M, Christiansen K, McRee B, Vendetti J (2002) Cognitive functioning of longterm heavy cannabis users seeking treatment. JAMA 287:1123-1131.

Stella N, Piomelli D (2001) Receptor-dependent formation of endogenous cannabinoids in cortical neurons. Eur J Pharmacol 425:189-196.

Stella N, Schweitzer P, Piomelli D (1997) A second endogenous cannabinoid that modulates long-term potentiation. Nature 388:773-778.

Stence N, Waite M, Dailey ME (2001) Dynamics of microglial activation. Glia 33:256-266.

Sugiura T, Kondo S, Sukagawa A, Nakane S, Shinoda A, Itoh K, Yamashita A, Waku K (1995) 2-Arachidonoylglycerol: a possible endogenous cannabinoid receptor ligand in brain. Biochem Biophys Res Commun 215:89-97.

Sugiura T, Kondo S, Kishimoto S, Miyashita T, Nakane S, Kodaka T, Suhara Y, Takayama H, Waku K (2000) Evidence that 2-arachidonylglycerol but not $N$-palmitpylethanolamine or anandamide is the physiological ligand for the cannabinoid CB2 receptor. J Biol Chem 275:605-612.

Tsou K, Brown S, Sanudo-Pena MC, Mackie K, Walker JM (1998) Immunohistochemical distribution of cannabinoid $\mathrm{CB} 1$ receptors in the rat central nervous system. Neuroscience 83:393-411.

Wade CB, Robinson S, Shapiro R, Dorsa DM (2001) Estrogen receptor (ER)a and ERb exhibit unique pharmacological properties when coupled to activation of the mitogen-activated protein kinase pathway. Endocrinology 142:2336-2342.

Wagner JA, Varga K, Ellis EF, Rzigalinski BA, Martin BR, Kunos G (1997) Activation of peripheral CB1 cannabinoid receptors in haemorrhagic shock. Nature 390:518-521.

Waksman Y, Olson JM, Carlisle SJ, Cabral GY (1999) The central cannabinoid receptor (CB1) mediates inhibition of nitric oxide production by rat microglial cells. J Pharmacol Exp Ther 288:1357-1366.

Walter L, Franklin A, Witting A, Möller T, Stella N (2002) Astrocytes in culture produce anandamide and other acylethanolamides. J Biol Chem 277:20869-20876.

Watanabe N, Mitchison TJ (2002) Single-molecule speckle analysis of actine filament turnover in lamellipodia. Science 295:1083-1087.

Watson SJ, Benson JA, Joy JE (2000) Marijuana and medicine: assessing the science base. Arch Gen Psychiatry 57:547-552.

Wilkinson PC (1998) Assays of leucocyte locomotion and chemotaxis. J Immunol Methods 216:139-153.

Wilson RI, Nicoll RA (2001) Endogenous cannabinoids mediate retrograde signalling at hippocampal synapses. Nature 410:588-592.

Wirguin I, Mechoulam R, Breuer A, Schezen E, Weidenfeld J, Brenner T (1994) Suppression of experimental autoimmune encephalomyelitis by cannabinoids. Immunopharmacology 28:209-214.

Zimmer A, Zimmer AM, Hohmann AG, Herkenham M, Bonner TI (1999) Increased mortality, hypoactivity, and hypoalgesia in cannabinoid CB1 receptor knockout mice. Proc Natl Acad Sci USA 96:5780-5785. 